\title{
Effect of Cassava based diet on hepatic proteins in albino rats fed with crude oil contaminated diet
}

\section{${ }^{1}$ BRAIDE, A. SOLOMON; ${ }^{2}$ ADEGOKE, O. ADEBAYO; ${ }^{3}$ BAMIGBOWU, E. OLUGBENGA}

\author{
Institute of Pollution Studies, Rivers State University of Science and Technology, Port Harcourt.+2348023124938 \\ ${ }^{2}$ Department of Medical Laboratory Science, Rivers State University of Science and Technology, Port Harcourt. \\ E-mail bayoadeghq@yahoo.com,Tel +2348037103687 \\ ${ }^{3}$ Department of Chemical Pathology, College of health science, University of Port Harcourt, Port Harcourt. \\ E-maileogbenga@yahoo.com,Tel+2348033380957
}

\begin{abstract}
The study was carried out to ascertain the glucose effect of a cassava based diet (garri) on crude oil hepatotoxicity in albino rats by feeding diet contaminated with various concentrations of crude oil mixed with $20 \%$ gari to determine the protective effect of gari. The hepatic enzymes aspartate amino transferase (AST), alanine amino transferase (ALT), gamma glutamyl transpeptidase (GGT) and alkaline phosphatase (ALK PHOS) activities with albumin, Total protein and liver /body weight were monitored in the animals. Gari feeding at $20 \%$ caused dose dependent reduction in enzymes activities (ALT, AST, GGT and ALKPHOS) with dose dependent increases in albumin and Protein in gari fed albino rats compared with Petroleum fed albino rats $(\mathrm{P}<0.05)$ suggesting that gari reversed the hepatotoxic effect of crude oil. Dose dependent increase in enzymes activities and dose dependent decrease in proteins was observed in petroleum fed rats compared with their controls $(\mathrm{P}<0.05)$. The study showed that ingestion of petroleum contaminated diet caused increase activities of liver enzymes namely ALKPHOS, AST, ALT and GGT and decreased Protein concentrations, an indicator of possible liver damage but supplementation of the diet with $20 \%$ Gari lowered the increased activities of ALKPHOS, AST, ALT and GGT observed in the Petroleum contaminated diet while increasing the Protein concentration. This study showed that feeding on gari diet reversed the liver damage caused by crude petroleum as evidenced by reduced release of liver enzymes through glucose effect. @ JASEM
\end{abstract}

Crude oil which may be broadly characterised as paraffinic, naphtanic or aromatic (Chapelle, 1993) also contains smaller proportions of non hydrocarbon compounds such as oxygen, thiols, heterocyclic nitrogen and sulphur compounds as well as metalloporphyrins (Chapelle, 1993, Anoliefo, 1991, Traven, 1992). The organic substances are primarily and principally compounds comprising of carbon and hydrogen otherwise referred to as hydrocarbons. Crude petroleum contains hundreds of compounds and the chemical composition varies between geologic formations (Coppock et al 1995). They have also been grouped into types as light, medium (Intermediate) and heavy depending on their density, physical and chemical properties. The route of administration is mostly oral and external application for burns and wounds. In several organs, mainly heart and liver, cell damage is followed by increased activities of a number of cytoplasmic enzymes in the blood, a phenomenon that provides the basis for clinical diagnosis of diseases e.g. liver enzymes are usually raised in acute hepatotoxicity but tend to decrease with prolonged intoxication due to damage to the liver cells. The Nigerian Bonny crude oils are classified as light crude oils, with aromatic hydrocarbons accounting for up to $45 \%$ of the total hydrocarbons.

Glucose feeding in both man and microorganism causes profound changes in metabolism including inhibition of induction of several enzymes, stimulation of others and blockage of most effects of glucocorticods (Melvin and Goldberg, 1975). Cassava is a staple food in human diets in over 80 countries (Gomez, et al 1988). Gari a starchy food prepared from cassava (Manihot utilisima) tubers is one of the most popular staple foods of the people of the rain forest belt of West Africa and contains mainly starch-20\% amylase and $70 \%$ amylopectin having lost the soluble carbohydrates (i.e. glucose and sugar) during processing. An overall reduction in the activity of the succinate dehydrogenase and cytochrome c oxidase has been reported in albino mice fed on maize (control) and gari (a dried cassava product) based diets for 5 weeks (Ezeji, et al 2009) while Chilaka et al.,(1985) reported changes in the activity rates of glucose-6-phosphatase,NADPHcytochrome c $\left(\mathrm{P}_{-450}\right)$ reductase, NADPHdichlorophenol indophenol reductase, cytochrome $\mathrm{P}_{450}$ peroxidase and aniline hydroxylase and glucose6- phosphatase in rats fed Gari $(56 \% \mathrm{w} / \mathrm{w})$ for 9 weeks. The aim of this study is to determine the effect of gari diet on hepatotoxic effect caused by crude oil in albino rats using aspartate aminotransferase (AST), alanine aminotransferase (ALT), alkaline phosphatase (Alkphos), Gamma glutamyl transpeptidase (GGT), serum total protein and albumin as indicators. 


\section{MATERIALS AND METHODS}

Test Animals: Ninety Wistar albino rats of $0.195 \mathrm{~kg}$ average body weight on normal rat diet were obtained from the animal house of the department of Pharmacology and Toxicology, University of Port Harcourt. These rats were fed adlibitum with normal rat pellet and water and acclimatized to laboratory conditions for a period of 14days prior to commencement of study. The gari used in this study was purchased from Mile 3 Market, Port Harcourt. The crude petroleum used (Bonny Light) was obtained from the Nigerian National Petroleum Corporation (N.N.P.C.) Zonal Office at Moscow Road, Port Harcourt. Commercially prepared Alanine aminotransferase, aspartate aminotransferase, Total Protein and Albumin reagents were obtained from Randox Diagnostics, London while alkaline phosphatase and gammaglutamyltranspeptidase reagents were obtained from Quimica Clinica Aplicada (QCA) Spain

Animal Studies: Preliminary study was done to ascertain the oral $\mathrm{LD}_{100}$ (Akaninwor et al 2006) of crude petroleum by feeding 30 albino rats divided into six groups of five animals each with crude oil at concentrations of 63.90, 109.00, 127.80, 191.70 and $255.60 \mathrm{~g} / \mathrm{kg}$ while the last group was given normal saline to serve as control and the number of death monitored in all the groups and recorded. The $\mathrm{LD}_{50}$ was done by Arithmetic method of Karber (Dede, and Igbigbi, 1997). Preliminary study was also done by authors to ascertain the gari concentration that will cause glucose effect by feeding rats with various concentrations of gari and observing the concentration of gari with the lowest enzymes level.

Biochemical Studies: Determination of ALT and AST was done by monitoring the concentrations of pyruvate hydrazone formed with 2, 4 dinitrophenylhydrazine. $0.5 \mathrm{ml}$ of buffer solution was dispensed into test tubes labeled blank, sample, control blank and control respectively for AST and ALT respectively. $0.1 \mathrm{ml}$ of sample and control was dispensed into their respective test tubes. All the tubes were incubated at $37^{\circ} \mathrm{C}$ for 30 minutes. $0.5 \mathrm{ml}$ of 2, 4 dinitrophenylhydrazine was dispensed into all test tubes. $0.1 \mathrm{ml}$ of sample and control was dispensed into their respective blank test tube. The contents of each test tube was mixed and allowed to stand for 20 minutes at $25^{\circ} \mathrm{C} .5 \mathrm{ml}$ of $0.4 \mathrm{~N}$ sodium hydroxide was added to each tube, mixed and read at $550 \mathrm{~nm}$ against the respective blank prepared. The activity of the unknown was extrapolated from the calibration curve already prepared (Reitman, and Frankel, 1957).
Alkaline Phosphatase activity was done by Phenolphthalein Monophosphate method .The test tubes were respectively labeled sample, standard and control. $1.0 \mathrm{ml}$ of distilled water was pipetted into each tube followed by a drop of the substrate into each test tube. All the test tubes were incubated at $37^{\circ} \mathrm{C}$ for 5 minutes. $0.1 \mathrm{ml}$ of sample, standard and control were dispensed into their respective test tubes. The test tubes were incubated at $37^{\circ} \mathrm{C}$ for 20 minutes. $5 \mathrm{ml}$ of colour developer was added to each test tube, mixed, and read at 550nm using water as blank. The activity of sample was calculated using the absorbance of sample against absorbance of standard multiplied by concentration of standard (Babson et al 1966).

Gamma Glutamyl Transpeptidase was done by Modified Szasz method (Szasz 1969). 2.0ml of working reagent (Substrate dissolved in Buffer according to manufacturer's specification) was pipetted into test tube and incubated at $37{ }^{\circ} \mathrm{C}$ for 3 minutes. $0.2 \mathrm{ml}$ of serum sample was added into the test tube mixed and transferred into measuring cuvette. The absorbances were read at $\mathrm{O}, 1,2$ and 3 minutes using water as blank at wavelength of $405 \mathrm{~nm}$. The activity of Gamma glutamyltranspeptidase was calculated by multiplying mean change in absorbance per minute with a factor (1158).

Total Protein concentration was carried out using Biuret method. $5.0 \mathrm{ml}$ of Biuret reagent was pipetted into tubes labeled blank, standard, test, and control. $0.1 \mathrm{ml}$ of distilled water, standard, sample and control were pipetted into their respective tubes, mixed and incubated for 30 minutes at $25^{\circ} \mathrm{C}$. The absorbances were measured against the reagent blank at wavelength of $546 \mathrm{~nm}$. The concentration of total protein was calculated by dividing the absorbance of sample against absorbance of standard multiplied by concentration of standard (Henry et al 1974).

Bromocresol green (BCG) method by Doumas et al.,(1971) was used for albumin estimation. $3 \mathrm{ml}$ of Bromocresol green reagent was pipetted into tubes labeled blank, standard, sample and control. $0.01 \mathrm{ml}$ of distilled water, standard, sample and control was pipetted into their respective tubes, mixed and incubated at $25{ }^{\circ} \mathrm{C}$ for 5 minutes. The absorbances were measured at $578 \mathrm{~nm}$ against the reagent blank. The concentration of Albumin was determined by dividing the absorbance of sample against absorbance of standard multiplied by concentration of standard.

The liver to body weight ratio was determined by taking the weight of the whole liver and comparing it with the final body weight as described by Sunmonu and Oloyede (2007). 
Statistical Analysis: The biochemical data were subjected to some statistical analysis. Values were reported as Mean \pm SEM while student's t-test was used to test for differences between treatment groups using Statistical Package for Social Sciences (SPSS) version 16.A value of $\mathrm{P}<0.05$ was accepted as significant.

\section{RESULTS AND DISCUSSION}

The oral lethal dose $100\left(\mathrm{LD}_{100}\right)$ and lethal dose 50 $\left(\mathrm{LD}_{50}\right)$ obtained in this study, $255.60 \pm 0.195 \mathrm{~g} / \mathrm{kg}$ and $124.04 \pm 0.195 \mathrm{~g} / \mathrm{kg}$ respectively is similar to the $\mathrm{LD}_{100}$ and $\mathrm{LD}_{50}$ obtained by Akaninwor et al., (2006) for Bonny light crude petroleum $(254.80 \mathrm{~g} / \mathrm{kg}$ and $108.30 \mathrm{~g} / \mathrm{kg}$ ) and Forcados crude petroleum $(254.60 \mathrm{~g} / \mathrm{kg}$ and $150.70 \mathrm{~g} / \mathrm{kg})$ respectively as shown in Table 1. Most of the substances contained in crude petroleum occur naturally due to their presence in rock formation or in saltwater deposits from which the crude oil was drawn (Anon, 1973). However some of these are also introduced from the drilling pipes and drilling fluid additives while others are introduced during pumping, preparing and transporting of crude oil (IARC 1989). They are also introduced greatly in the relative concentrations of different components and thus show substantial variability in solubility, dispensability, persistence and toxicity (Anderson et al 1982). LD $_{50}$ values depend on the route of administration as the values are found to increase with the following sequences of route: intravenous, intraperitoneal, subcutaneous and oral (Turner 1969). The highest dose of crude petroleum selected for the study was half of $\mathrm{LD}_{50}$ which was considered tolerable for the period of study.

Table 1 Determination Of Median Lethal Dose $\left(\operatorname{Ld}_{50}\right)$ Of Albino Rats Treated With Bonny Light Crude Petroleum, $\mathrm{n}=5, \quad \mathrm{LD} 50(\mathrm{~g} / \mathrm{kg})=$ $124.04 \pm 0.195 \mathrm{~g} / \mathrm{kg}$.

\begin{tabular}{lccc}
\hline Group & Dose level g/kg & No of death(s) recorded & Average time of Death(Hour) \\
\hline 1 & 0.00 & 0 & 0.00 \\
2 & 63.90 & 1 & 20.00 \\
3 & 109.00 & 2 & 15.00 \\
4 & 127.80 & 3 & 13.00 \\
5 & 191.70 & 4 & 9.00 \\
6 & 255.60 & 5 & 6.00 \\
\hline
\end{tabular}

There were doses dependent increase in Alkaline phosphatase activity (U/L), Aspartate amino transferase activity (U/L) and alanine amino transferase activity (U/L) in both Petroleum treated and gari treated albino rats with gari treated rats lower in activity compared with petroleum treated. The Alkaline phosphatase activity (U/L) showed dose dependent increase. The alkaline phosphatase activity of Petroleum treated albino rats of the control was $43.80 \pm 4.37$. At $3.88 \mathrm{~g} / \mathrm{kg}$ of petroleum treatment, the alkaline phosphatase activity was $41.80 \pm 6.66$, while it increased to $51.80 \pm 4.94,64.00 \pm 4.57,63.60$ \pm 8.82 and $66.20 \pm 9.30$ at concentrations of 7.75 , $15.51,31.01$ and $62.02 \mathrm{~g} / \mathrm{kg}$ respectively. The alkaline phosphatase activity of control in gari treated albino rats was $41.60 \pm 4.27$. At $3.88 \mathrm{~g} / \mathrm{kg}$ of gari treatment, the alkaline phosphatase activity was $28.20 \pm 8.58$, while it increased to $32.80 \pm 5.23,43.40 \pm 5.07$, $40.60 \pm 6.38$ and $44.80 \pm 3 . \overline{43}$ at concentrations of $7.75,15.51,31.01$ and $62.02 \mathrm{~g} / \mathrm{kg}$ respectively as shown below in table 2 .

The Aspartate amino transferase activity (U/L) of $14.40 \pm 3.19$ was obtained in the control of petroleum treated albino rats which increased to $19.00 \pm 4.72$ at $3.88 \mathrm{~g} / \mathrm{kg}$. The Aspartate amino transferase activity further increased to $27.00 \pm 5.27,32.40 \pm 5.24,38.40$ \pm 4.96 and $51.40 \pm 5.81$ at concentrations of 7.75 ,
15.51, 31.01 and $62.02 \mathrm{~g} / \mathrm{kg}$ respectively. The Aspartate amino transferase activity of $14.80 \pm 3.40$ was obtained in the control of gari treated albino rats which increased to $16.40+4.61$ at $3.88 \mathrm{~g} / \mathrm{kg}$. The Aspartate amino transferase activity further increased to $18.80 \pm 3.01,21.60 \pm 3.01,26.00 \pm 5.62$ and 28.20 \pm 4.19 at concentrations of $7.75,15.51,31.01$ and $62.02 \mathrm{~g} / \mathrm{kg}$ respectively as shown below in table 2 .

The alanine amino transferase activity of $12.80 \pm$ 0.58 was obtained in the control of petroleum treated albino rats which increased to $14.00 \pm 1.14$ at $3.88 \mathrm{~g} / \mathrm{kg}$. The alanine amino transferase activity further increased to $21.00 \pm 3.77,24.20 \pm 5.50,26.00$ \pm 4.01 and $29.20 \pm 6.26$ at concentrations of 7.75 , $15.51,31.01$ and $62.02 \mathrm{~g} / \mathrm{kg}$ respectively. The alanine amino transferase activity of $11.40 \pm 1.50$ was obtained in the control of gari treated albino rats which reduced to $10.80 \pm 2.82$ at $3.88 \mathrm{~g} / \mathrm{kg}$. The alanine amino transferase activity further increased to $12.20 \pm 2.87,12.90 \pm 2.08,16.80 \pm 5.57$ and $17.80 \pm$ 2.61 at concentrations of $7.75,15.51,31.01$ and $62.02 \mathrm{~g} / \mathrm{kg}$ respectively as shown below in table 2 .

The dose dependent increases in Alkaline phosphatase activity (ALKPHOS), Aspartate amino transferase activity (AST) and alanine amino tranferase activity (ALT) of rats fed crude petroleum 
contaminated diet compared with their controls is similar to the studies by Sunmonu and Oloyede (2006), Orisakwe et al.,(2005), Ayalogu et al., (2001), Dede et al., (2001) and Ologunde et al., (2008) while the gari study groups showed significant dose dependent reduction in ALKPHOS,AST and ALT compared with petroleum study group. The suppression of enzymes by gari in this study is similar to report of Chilaka et al.,(1985) and Ezeji et al., (2009). Feeding a diet high in simple carbohydrates to rats or mice results in increased transcription of at least 15 genes involved in glucose uptake, glycolysis and lipogenesis (Towle et al., 1997).Feeding on gari might have caused reduction in enzyme induction through lowering cyclic AMP level known as glucose effect. The gari feeding might have lowered cAMP in crude oil treated albino rats thus inhibiting induction of these enzymes.

Table 2. Effect Of Gari On Alkaline Phosphatase, Aspartate Amino Transferase And Alanine Amino Transferase In Albino Rats Treated



The gammaglutamyl transpeptidase activity (U/L) of control in Petroleum treated albino rats was $557.40 \pm$ 52.18. At $3.88 \mathrm{~g} / \mathrm{kg}$ of petroleum treatment, the gammaglutamyl transpeptidase activity was $523.80 \pm$ 97.27, while it increased to $612.00 \pm 182.09,617.60$ $\pm 77.56,807.60 \pm 93.25$ and $825.00 \pm 131.84$ at concentrations of $7.75,15.51,31.01$ and $62.02 \mathrm{~g} / \mathrm{kg}$ respectively. The gammaglutamyl transpeptidase activity of control in gari treated albino rats was $530.80 \pm 50.36$. At $3.88 \mathrm{~g} / \mathrm{kg}$ of gari treatment, the gammaglutamyl transpeptidase activity was $296.20 \pm$ 92.21, while it increased to $424.60 \pm 53.67,422.00 \pm$ $110.56,718.00 \pm 65.30$ and $750.40 \pm 130.57$ at concentrations of $7.75,15.51,31.01$ and $62.02 \mathrm{~g} / \mathrm{kg}$ respectively as shown below in table 3 . The enzyme gammaglutamyl transpeptidase (GGT) is widely used as a marker in preneoplastic lesions in the liver during chemical carcinogenesis (Peraino et al., 1983) but glucose feeding in both man and microorganisms causes profound changes in metabolism including inhibition of induction of several enzymes, stimulation of others and blockage of most effects of glucocorticoids (Melvin and Goldberg, 1975), thus feeding on gari diet has blocked the induction of GGT. Gari feeding possibly caused inhibition of GGT by lowering cyclic AMP level as shown below in table 3 .

Table 3. Effect of gari on gamma glutamyl transpeptidase in albino rats treated with petroleum

\begin{tabular}{cllcc}
\hline Concentration $(\mathrm{g} / \mathrm{kg})$ & Petroleum treated & Gari treated & $\mathrm{t}$ & $\mathrm{P}$ \\
\hline $\mathbf{0 . 0 0}$ & $557.40 \pm 52.18$ & $530.80 \pm 50.36$ & 0.668 & 0.541 \\
3.88 & $523.80 \pm 97.27$ & $296.20 \pm 92.21$ & 1.782 & 0.149 \\
7.75 & $612.00 \pm 182.09$ & $424.60 \pm 53.67$ & 0.808 & 0.464 \\
15.51 & $617.60 \pm 77.56$ & $422.00 \pm 110.56$ & 1.605 & 0.184 \\
31.01 & $807.60 \pm 93.25$ & $718.00 \pm 65.30$ & 1.062 & 0.348 \\
62.02 & $825.00 \pm 131.84$ & $750.40 \pm 130.57$ & 0.369 & 0.731 \\
\hline
\end{tabular}

The Total protein and albumin concentrations $(\mathrm{g} / \mathrm{l})$ showed dose dependent decrease in both petroleum and Gari treated albino rats with the petroleum treated lower in concentration than the gari treated. The control albino rats had protein concentrations $(\mathrm{g} / \mathrm{l})$ of $66.00 \pm 3.81$ and $65.60 \pm 5.42$ in both petroleum and gari treated rats respectively. The protein concentration at $3.88 \mathrm{~g} / \mathrm{kg}$ of petroleum treated albino rats was $66.20 \pm 2.13$. At $7.75 \mathrm{~g} / \mathrm{kg}$ the protein concentration was $66 . \overline{6} 0 \pm 1.89$ but decreased to $63.00 \pm 3.36,61.00 \pm 2.36$ and $61.40 \pm 2.31$ at $15.51,31.01$ and $62.02 \mathrm{~g} / \mathrm{kg}$ respectively. The total protein concentration $(\mathrm{g} / \mathrm{l})$ of gari treated albino rats was $73.60 \pm 5.03,71.00 \pm 2.78,66.20 \pm 5.38,66.00 \pm$ 3.96 , and $63.60 \pm 1.72$ at concentrations of 3.88 , $7.75,15.51,31.01$ and $62.02 \mathrm{~g} / \mathrm{kg}$ respectively as shown below in table 4 .

The control albino rats had albumin concentrations $(\mathrm{g} / \mathrm{l})$ of $38.60 \pm 0.68$ and $39.40 \pm 3.04$ in both petroleum and gari treated rats respectively. The albumin concentration at $3.88 \mathrm{~g} / \mathrm{kg}$ of petroleum treated albino rats was $38.40 \pm 1.91$. At $7.75 \mathrm{~g} / \mathrm{kg}$ the albumin concentration was $36.60 \pm 2.31$, which decreased to $36.40 \pm 0.68,35.40 \pm 1.66$ and $35.20 \pm$ 1.02 at $15.51,31.01$ and $62.02 \mathrm{~g} / \mathrm{kg}$ respectively. The 
albumin concentration $(\mathrm{g} / \mathrm{l})$ of gari treated albino rats was $40.60 \pm 2.99,41.20 \pm 3.40,39.20 \pm 3.40,37.20 \pm$ 4.26 and $37.60 \pm 2.09$ at concentrations of $3.88,7.75$, $15.51,31.01$ and $62.02 \mathrm{~g} / \mathrm{kg}$ respectively as shown below in table 4 . The liver/body weight ratio of Petroleum treated albino rats of the control was 10.00 \pm 1.05 while it was $10.60 \pm 0.51$ in the gari treated albino rats. At $3.88 \mathrm{~g} / \mathrm{kg}$ of petroleum treatment, the liver/body weight ratio was $9.90 \pm 0.84$ which reduced further to $8.36 \pm 0.31,5.98 \pm 1.67,5.36 \pm$ 0.26 and $5.22 \pm 0.48$ at concentrations of $7.75,15.51$, 31.01 and $62.02 \mathrm{~g} / \mathrm{kg}$ respectively. The liver/body weight ratio in gari treated albino rats was $9.96 \pm$ 0.67 at $3.88 \mathrm{~g} / \mathrm{kg}$. At $7.75 \mathrm{~g} / \mathrm{kg}$ gari treatment, the liver/body weight ratio was $9.68 \pm 0.45,6.54 \pm$ $1.32,5.46 \pm 0.57$ and $5.36 \pm 0.41$ at concentrations of $15.51,31.01$ and $62.02 \mathrm{~g} / \mathrm{kg}$ respectively as shown below in table 4 .

The significant dose dependent decrease in total protein (TPROT) concentrations in crude petroleum treated albino rats is in agreement with the work of Sunmonu and Oloyede (2007). The significant dose dependent reduction in total protein and serum albumin concentrations may be a consequence of poor diet, caused by the effect of crude oil or an indication of liver dysfunction amongst others. Thus, it is possible that the contaminated diet consumed by the rats which contains toxic compounds like polycyclic aromatic hydrocarbons (an important constituent of crude oil) may affect the liver thereby preventing it from synthesizing enough total protein and albumins for release into the serum. This effect was also supported by the reduction in the liver to body weight ratio which can be attributed to abnormality in nutrient absorption by the liver from the crude oil contaminated diet. Significant dose dependent reduction in the liver to body weight ratio of the crude petroleum treated has been reported by Berepubo et al., (1994),Ovuru et al., (2003) and Sunmonu and Oloyede (2007). Jacob and Al Muzaini (1995) observed that petroleum pollution could range from diffused chronic exposure to considerably large single doses. These subtlethal concentrations may not necessarily lead to outright mortality but may have significant effects which can lead to physiological stress and dysfunctions in animals (Omoregie, 1998). These effects were reversed by the gari diet causing increases in protein and albumin synthesis and increase liver/body weight ratio but not significantly probably as result of the feeding duration.

Table 4 Effect of gari on total protein,albumin and liver/body weight ratio in albino rats treated with petroleum

\begin{tabular}{|c|c|c|c|c|c|c|c|c|c|}
\hline & total protein $(\mathrm{g} / \mathrm{l})$ & & & albumin $(g / l)$ & & & liver/body weight 1 & & \\
\hline $\begin{array}{c}\text { concentration } \\
(\mathrm{g} / \mathrm{kg})\end{array}$ & petroleum treated & $\begin{array}{l}\text { gari } \\
\text { treated }\end{array}$ & $\mathrm{p}$ value & petroleum treated & $\begin{array}{l}\text { gari } \\
\text { treated }\end{array}$ & $\mathrm{p}$ value & petroleum treated & $\begin{array}{l}\text { gari } \\
\text { treated }\end{array}$ & $\mathrm{p}$ value \\
\hline 0.00 & $66.0 \pm 3.81$ & $65.6 \pm 5.42$ & 0.910 & $38.6 \pm 0.68$ & $39.4 \pm 3.04$ & 0.817 & $10.0 \pm 1.05$ & $10.6 \pm 0.51$ & 0.646 \\
\hline 15.51 & $63.0 \pm 3.36$ & $66.2 \pm 5.38$ & 0.305 & $36.4 \pm 0.68$ & $39.2 \pm 3.40$ & 0.519 & $5.9 \pm 1.67$ & $6.5 \pm 1.32$ & 0.142 \\
\hline 31.01 & $61.0 \pm 2.36$ & $66.0 \pm 3.96$ & 0.391 & $35.4 \pm 1.66$ & $37.2 \pm 4.26$ & 0.748 & $5.3 \pm 0.26$ & $5.4 \pm 0.57$ & 0.892 \\
\hline 62.02 & $61.4 \pm 2.31$ & $63.6 \pm 1.72$ & 0.414 & $35.2 \pm 1.02$ & $37.6 \pm 2.09$ & 0.294 & $5.2 \pm 0.48$ & $5.3+0.41$ & 0.843 \\
\hline
\end{tabular}

Overall, there was significant difference in $57.48 \pm$ 4.66 alkaline phosphatase (U/L) activity of Petroleum fed rats compared with $38.57 \pm 2.40$ of gari fed rats. Also ALT (U/L) activity of $22.88 \pm 2.59$ in petroleum treated rats was significantly different from $13.63 \pm$ 1.28 in gari treated rats. The AST (U/L) activity of $33.64 \pm 5.47$ in petroleum treated rats was significantly different from $20.97 \pm 1.83$ in gari treated albino rats. The GGT activity (U/L) of 677.20 \pm 59.24 in petroleum treated rats was significantly different from $523.67 \pm 44.94$ in gari treated rats. The total protein $(\mathrm{g} / \mathrm{l})$ also was significantly different between the $63.56 \pm 1.21$ of petroleum treated rats and $67.67 \pm 1.71$ of gari treated rats. There was no significant difference in albumin $(\mathrm{g} / \mathrm{l})$ concentration of $36.40 \pm 0.57$ in petroleum treated rats and $39.20 \pm$ 1.24 of gari treated rats. There was no significant difference in $6.96 \pm 0.92$ liver/body weight ratio of Petroleum fed rats compared with $7.40 \pm 1.01$ of gari fed rats as shown in table 5 below.
There was overall reduction in the activities of ALKPHOS, AST, ALT and GGT in gari fed albino rats compared with petroleum fed albino rats. Glucose represses the induction of inducible operons by inhibiting the synthesis of cyclic Adenosine monophosphate (cAMP) a nucleotide that is required for the initiation of transcription of a large number of inducible enzyme systems including the Lac operon. Cyclic AMP (cAMP) is required to activate an allosteric protein called catabolite activator protein (CAP) which binds to the promoter CAP site and stimulates the binding of Ribonucleic acid (RNA) polymerase to the promoter for the initiation of transcription, but cAMP must be available to bind to CAP which binds to Deoxyribonucleic acid (DNA) to facilitate transcription. In the presence of glucose, adenylase cyclase (AC) activity is blocked. AC is required to synthesize cAMP from Adenosine Triphosphate (ATP) (Zubay et al.,1970 and Todar, 2008). Therefore if cAMP levels are low, CAP is inactive and transcription does not occur. Thus the 
effect of glucose in suppressing these inducible enzymes is by lowering cyclic AMP level. The gari feeding might have lowered cAMP in crude oil treated albino rats thus causing inhibition of these inducible enzymes.

\begin{tabular}{|c|c|c|c|}
\hline Parameter & Petroleum treated & Gari treated & $P$ value \\
\hline ALKPHOS(U/L) & $57.48 \pm 4.66$ & $38.57 \pm 2.40$ & 0.000 \\
\hline $\operatorname{ALT}(\mathrm{U} / \mathrm{L})$ & $22.88 \pm 2.59$ & $13.63 \pm 1.28$ & 0.003 \\
\hline $\mathrm{AST}(\mathrm{U} / \mathrm{L})$ & $33.64+5.47$ & $20.97 \pm 1.83$ & 0.000 \\
\hline GGT(U/L) & $677.20 \pm 59.24$ & $523.6 \overline{7} \pm 44.94$ & 0.027 \\
\hline T. PROT(g/l) & $63.56 \pm 1.21$ & $67.67 \pm 1.71$ & 0.015 \\
\hline $\operatorname{ALB}(\mathrm{g} / \mathrm{l})$ & $36.40 \pm 0.57$ & $39.20 \pm 1.24$ & 0.107 \\
\hline Liver/Body weight & $6.96+0.92$ & $7.40 \pm 1.01$ & 0.348 \\
\hline
\end{tabular}

Conclusion: This study has shown that feeding crude oil contaminated diets causes hepatotoxicity while feeding on gari reversed the hepatotoxicity by repressing the induced enzymes caused by crude oil due to glucose effect. Glucose effect of carbohydrate diets could help in reducing liver dysfunction caused by petroleum as shown in this study.

Acknowledgement: We wish to thank the Management of Labmedica Services for some of the analysis and Mr Enyaosa Tony for some literatures used in this study.

\section{REFERENCES}

Akaninwor, J.O., Okeke, E.A., and Ayalogu, E. O. (2006): Effect of diets contaminated with crude petroleum products (Bonny light and Forcados) on the haematological parameters of Wistar albino rats. Journal of Nigerian Environmental Society, 3 (3):160-166.

Anderson, K. E., Conney, A. H. and Kappas, A.(1982). Nutritional influences on chemical biotransformations in humans. Nutrition Review, 40: $161-171$.

Anoliefo, G. O.,(1991). Forcados blend oil effect on respiration metabolism, mineral element composition and growth of Citrulus vulgaris. Ph.D Thesis University of Benin ,Benin City Nigeria.

Anon, O.(1973). Evaluation of World's important crude. The Petroleum Publishing Company; Oklahoma USA, 60

Ayalogu, O. E., Igboh, N. M. and Dede, E. B.,(2001).Biochemical Changes in the serum and liver of albino rats exposed to petroleum samples (Gasoline, Kerosene and Crude Petroleum). Journal of Applied science and environment Management, 5 (1): 97-100.
Babson, L. A., Greeley, S. J., Coleman, C. M., Philips, G. D.(1966). Phenolphthalein monophosphate as a substrate for serum alkaline phosphatase. Clinical Chemistry, 12: 482 -490.

Berepubo, N. A. Johnson, N. C. and Sese, B. T.,(1994). Growth potential and organ weights of weaner rabbits exposed to crude oil contaminated feed. International Journal of Animal Science, 9:73-76.

Chapelle, F. H. (1993).Ground Water Microbiology and Geochemistry, John Wiley and Sons, New York, 573.

Chilaka, F.C., Anosike, E.O. and Obidoa, O.(1985). Effect of high and prolonged gari diets on some microsomal enzymes activities of rat liver. Qual Plant Plant Foods Human Nutrition, 35:159-164.

Coppock, R. W., Mostrom, M.S., Khan, A., Semalula, S.S.(1995). Toxicology of oil field pollutants in cattle: A review. Veterinary and Human Toxicology, 37 (6): 369 - 576.

Dede, E. B., Igboh, N. M., Ayalogu, O. E.,(2001). Acute toxicity of crude petroleum (Bonny light) kerosene and gasoline in albino rats. Journal of Applied Science and Environmental Management, ;5 (2): 73 - 55.

Dede, E. B. and Igbigbi, P.S.(1997). Determination of $\mathrm{LD}_{50}$ of Metakelfin in rats. Journal of Science, Metascience, 111(1):1-7.

Doumas, B. T., Watson, W. A., Biggs, H. G., (1971).Albumin standards and the measurement of serum albumin with Bromocresol green. Clinical Chemistry Acta $; 31: 87$.

Ezeji, E. U., Obidua, O., Kalu, I. G. and Nwachukwu, I.N. (2009). Effect of Gari Diet on Marker Enzymes of Mice Liver Mitochondria. Pakistan Journal of Nutrition ;8 (4): 414-418. 
Gomez, G., Aparicho, M.A. and Willhite, C.C.(1988). Relationship between dietary cassava cyanide levels and brailer performance. Nutrition Report International; 37:63-75.

Henry, R.J., Cannon, D. C., Winkelman, J. W.(1974). Clinical Chemistry Principles and Techniques, Harper and Row 2nd Edition.

International Agency for Research on Cancer,(IARC)(1989). Monographs on the evaluation of the carcinogenic risk of chemical to Humans: Some industrial chemicals and dyestuffs. Lyon, 29:93.

Jacob, P. G., Al-Muzaini, A. (1995): Marine plants of the Arabian Gulf and effects of oil pollution. Mahasagar, 23: 83 - 101.

Melvin, L. and Goldberg, N. (1975). The glucose effect: carbohydrate repression of enzyme induction, RNA synthesis and glucocorticoid activity .a role for cyclic AMP and cyclic GMP. Journal of Life Science, 17 (12): 1747 - 1754.

Ologunde, M.O., Olaniyan, S.A., Fapojuwo, O.O. Liasu, M.O. and Olunlade, B. A.(2008). Haematological Parameters of Rats Fed on Prolonged Crude oil Contaminated CassavaBased Diet. American-Eurasian Journal of Sustainable Agriculture, 2(3): 242-248.

Omoregie, E. (1998): Changes in the haematology of the Nile tilapia(Oreochromis niloticus trewavas) under the effects of crude oil. Acta Hydrochimica et Hydrobiologica, 40: 287 - 292.

Orisakwe, O. E., Akumka, D. D.,Njan, A. A., Afonne, O. J., Okechi, O.O.(2005). Hepatotoxic and haematologic effects of Nigerian Bonny light Crude oil in male albino rats in: Toxicological and Environmental Chemistry, Taylor and Francis Publishers, 87 (2): 215 221.

Ovuru, S. S., Berepubo, N. A. and Etebu, E. N.( 2003).The effects of Weathered Crude Oil (Bonny light) on liver histology in semi-Adult rabbits. Journal of Nigerian Environmental Society, 1 (2): 193 - 198.
Peraino, C., Richards, W. Z. L. and Steven, F. J., (1983): Multistage - Hepatocarcinogenesis. Environmental Health Perspective, $\quad$ 50:1-53.

Reitman, S. and Frankel, S. A (1957). Colorimetric method for determination of serum glutamic oxaloacetic transaminase (SGOT) and serum glutamic pyruvic transaminase (SGPT). American Journal of Clinical Pathology,28: 56.

Sunmonu, T. O and Oloyede, O. B. (2006). Changes in liver enzyme activities in African catfish (Clarias gariepinus) exposed to crude oil. Asian Fishery Science, 19: 104-109.

Sunmonu, T. O. and Oloyede, O. B.(2007): Biochemical assessment of the effects of crude oil contaminated catfish (Clarias gariepinus) on the hepatocytes and performance of rat. African Journal of Biochemical Research, 1 (5) : 083 089.

Szasz, G. A(1969). kinetic photometric method for serum gammaglutamyl transferase .Clinical Chemistry,;15: 124 - 136.

Tietz, N. W. (1986).Albumin in: Fundamentals of clinical chemistry, WB Saunders Co Philadelphia ; Pp723

Todar, K.(2008). Regulation and Control of Metabolism in Bacteria: in: Todar's Online Textbook of Bacteriology. 1-5.

Towle, H. C., Kaytor, E. N., Shih, H. M., (1997): Regulation of the expression of lipogenic enzymes by carbohydrates. Annual Review of Nutrition, 17:405-433.

Traven, F.(1992). Frontier orbitals and properties of organic Molecules, Ellis Harwood Publishers London. 235-238.

Turner R. (1965).Acute toxicity: The determination of $\mathrm{LD}_{50}$ in: Screening Methods in Pharmacology, 1965; Academic Press New York 300.

Zubay, G., Schwartz, D., and Beckwith, J.(1970). Mechanism of activation of catabolite- sensitive genes: a positive control system. Proceedings of the National Academy of Sciences; 66(1): 104-110. 